Piotr Kasza

Instytut Nafty i Gazu - Państwowy Instytut Badawczy

Piotr Kenar, Wojciech Piętka

ORLEN Upstream

\title{
Specyfika udostępniania złóż niekonwencjonalnych w Polsce
}

Zasoby węglowodorów w złożach niekonwencjonalnych zaczynają odgrywać coraz większą rolę w globalnym bilansie energetycznym. Ich pozyskanie staje się wiodącym celem wielu firm naftowych z całego świata. Polski przemysł ma już pewne doświadczenia w tym obszarze poszukiwań. W minionych latach prowadzono prace nad uzyskaniem komercyjnej produkcji węglowodorów z łupków gazonośnych. Polskie firmy udostępniły formacje łupkowe znaczną liczbą odwiertów. Wiele z prac nad udostępnianiem tych formacji miało charakter eksperymentalny. Ich celem było znalezienie efektywnej techniki i technologii pozyskiwania gazu z łupków. Firma ORLEN Upstream wykonała interesujące prace stymulacyjne w odwiercie Stoczek-OU1K. Zabiegi szczelinowania zostały przeprowadzone z wykorzystaniem różnych technologii płynowych, a opróbowanie odwiertu odbywało się w sposób selektywny. Jednocześnie krajowe firmy wykazują coraz większe zainteresowanie również innymi, niekonwencjonalnymi akumulacjami gazu (np. tight gas). W Polsce istnieją potwierdzone zasoby gazu w niskoprzepuszczalnych piaskowcach, natomiast sposoby ich udostępniania dotychczas nie zawsze okazywały się efektywne. Intensywny rozwój w obszarze dodatków chemicznych, jak również ciekawe koncepcje w zakresie technologii zabiegowych pozwalają z optymizmem patrzeć na przyszłe wyzwania związane ze stymulacją złóż typu tight. Interesującym obszarem poszukiwań nowych zasobów gazu ziemnego w Polsce jest też metan zakumulowany w pokładach węgla. Po pierwszych, niezbyt udanych eksperymentach w latach dziewięćdziesiątych ubiegłego stulecia, mając na względzie postęp techniczny i technologiczny, jaki się od tego czasu dokonał, można ponownie przystąpić do realizacji projektów w tym obszarze, z nadzieją na większą efektywność. Wspomniane działania i aktywność krajowych firm w poszukiwaniu węglowodorów w niekonwencjonalnych akumulacjach mogą doprowadzić do wypracowania efektywnej metody udostępniania tych formacji, a w konsekwencji do osiągnięcia sukcesu komercyjnego.

Słowa kluczowe: złoża niekonwencjonalne, hydrauliczne szczelinowanie, gaz z łupków, metan z węgla.

\section{Completion of unconventional reservoirs in Poland}

The hydrocarbon resources in unconventional reservoirs are beginning to play an increasingly important role in the global energy mix. Their completion is becoming a leading target for many oil companies all over the world. Polish industry has already had some experience in this area of exploration. In recent years, lots of projects have been conducted to obtain commercial production of hydrocarbons from shale. Polish companies have drilled significant amount of wells, to shale gas formation. Much of the work to make available these formations has been experimental. Their goal, was to find effective techniques and technologies for the production of shale gas. The company ORLEN Upstream, has done some interesting stimulation work in the Stoczek-OU1K well. Fracturing treatments were performed in different wellbore technologies and testing was performed in a selective manner. Meanwhile, national companies are more and more interested in other unconventional gas accumulations. In Poland there are proven reserves of tight gas in low permeability sandstones, and methods of their stimulation have not always been effective. Intensive development in the area of chemical additives as well as interesting ideas in treatment technology, allow to be optimistic for the future challenges in the field of stimulation of tight gas reservoirs. An interesting area of exploration of new natural gas resources in Poland is also methane accumulated in coal seams. After previous unsuccessful experiments in the past years, new projects in this area can be realized with greater efficiency, having regard to the technical and technological progress which has been made. These activities will lead to the development of effective completion methods in terms of these formations and consequently to commercial success.

Key words: unconventional reservoirs, hydraulic fracturing, shale gas, methane coalbed. 


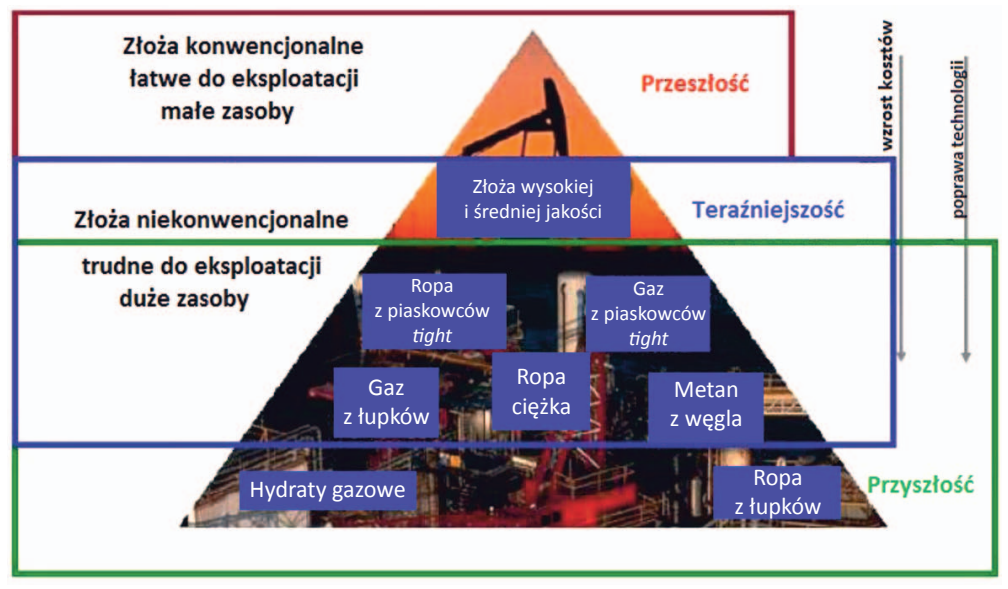

Rys. 1. Trójkąt zasobów

Pomimo zdarzających się od lat w różnych rejonach świata kryzysów ekonomicznych popyt na węglowodory jest nadal wysoki. Wraz z nim nie wzrasta liczba nowych odkryć złóż konwencjonalnych, dlatego już od pewnego czasu firmy poszukiwawcze coraz przychylniej spoglądają w kierunku akumulacji węglowodorów w formacjach niekonwencjonalnych. W nich upatrują głównego źródła przyszłych zasobów i możliwości zaspokojenia potrzeb rynku energetycznego. Jak wynika z dotychczas zebranych informacji, zasoby węglowodorów w złożach niekonwencjonalnych są znacznie większe niż potwierdzone zasoby zakumulowane w klasycznych złożach ropy i gazu. Niestety złoża niekonwencjonalne są znacznie trudniejsze do udostępnienia. Wymagają bardziej zaawansowanej techniki i technologii, dlatego pozyskiwanie ich zasobów jest kosztowniejsze niż w przypadku złóż konwencjonalnych. Stąd podjęcie decyzji o udostępnianiu złóż niekonwencjonalnych jest bardziej ryzykowne, a niejednokrotnie też zdarza się, że jest ekonomicznie nieopłacalne. Wielkość zasobów można graficznie przedstawić w postaci trójkąta (rysunek 1). Najmniejsze zasoby, lecz najłatwiej dostępne są reprezentowane w obszarze przy wierzchołku trójkąta. Największe zasoby, natomiast trudniej dostępne są zlokalizowane przy jego podstawie.

Znaczny potencjał wydobywczy potwierdzony został na świecie w formacjach łupkowych, złożach typu tight oraz w pokładach węgla, który akumuluje znaczne zasoby metanu. Wyniki „rewolucji” niekonwencjonalnej są bardzo zachęcające. W Stanach Zjednoczonych 37\% produkowanego gazu pochodzi z formacji łupkowych (źródło: IEA, 02.2013). Równie obiecujące rezultaty osiągnęły niektóre kraje w zagospodarowaniu metanu z pokładów węgla. Do światowych liderów w tym obszarze należą USA, Australia, Chiny oraz Indie.

Zgodnie z ukazującymi się publikacjami dotyczącymi krajowych zasobów metanu w formacjach niekonwencjonalnych mamy do czynienia ze sporym potencjałem. Nasze zasoby w złożach konwencjonalnych szacowane są na około
$145 \mathrm{mld} \mathrm{m}^{3}$. W formacjach typu tight ich wielkość określana jest na około $158 \mathrm{mld} \mathrm{m}^{3}$. Formacje łupkowe mogą mieć potencjał wydobywczy na poziomie około $346 \mathrm{mld} \mathrm{m}^{3}$, natomiast gaz zakumulowany w węglu to kolejne $95 \mathrm{mld} \mathrm{m}^{3}$. $\mathrm{Z}$ danych tych, pokazanych na rysunku 2, wynika, że w złożach niekonwencjonalnych w Polsce jest zgromadzone ponad czterokrotnie więcej gazu niż w złożach konwencjonalnych, co uzasadnia podejmowanie prób udostępniania i wydobycia węglowodorów $\mathrm{z}$ tych formacji.

Bez względu na typ akumulacji metanu najistotniejszą kwestią jest udostępnienie tych zasobów. Jedyną potwierdzoną, skuteczną metodą udostępniania złóż niekonwencjonalnych jest dziś hydrauliczne szczelinowanie. W każdym z wymienionych typów złóż szczelinowanie ma specyficzne i jasno określone zadania.

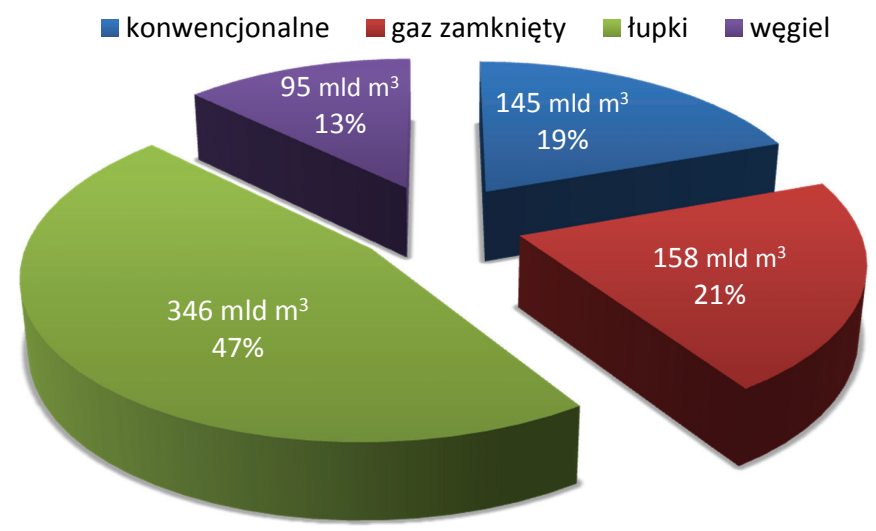

Rys. 2. Zasoby metanu w Polsce

Generalnie hydrauliczne szczelinowanie stosuje się w słabo i bardzo słabo przepuszczalnych złożach. Zgodnie z naturą złóż niekonwencjonalnych bez wykonania w nich zabiegów hydraulicznego szczelinowania nie można prowadzić ich ekonomicznej eksploatacji. Celem tej operacji jest kontrolowane wytworzenie w złożu podpartej szczeliny lub szczelin, przez co zwiększa się powierzchnię kontaktu odwiertu ze złożem, a podsadzona szczelina stanowi wysoko przepuszczalną arterię komunikacyjną do transportu węglowodorów. W złożach typu tight zabieg szczelinowania najmniej różni się od tego wykonywanego w złożach konwencjonalnych, natomiast ich współczynnik przepuszczalności jest wielokrotnie mniejszy. W efekcie istnieje konieczność występowania znacznych gradientów ciśnienia do przepływu gazu. Z uwagi na fakt, że gradient ciśnienia w złożu jest ograniczony, należy w celu maksymalnego zdrenowania matrycy utworzyć dwuskrzydłową szczelinę i „,dotrzeć” z nią jak najdalej. Do tego celu używa się tysięcy metrów sześciennych cieczy szczelinującej oraz setek ton materiału podsadzkowego. Do wytworzenia szczeliny znacznych rozmiarów 


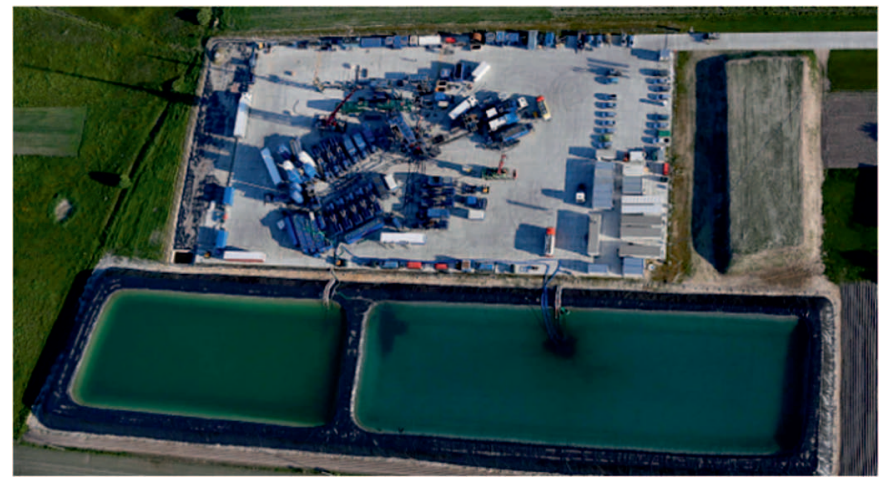

Rys. 3. Hydrauliczne szczelinowanie

(Archiwum ORLEN Upstream)

potrzebna jest też istotna moc hydrauliczna, zdolna pompować te materiały z dużą wydajnością i przy wysokim ciśnieniu. $\mathrm{Z}$ tego względu zabiegi te w złożach tight noszą nazwę „masowych” (MHF - massive hydraulic fracturing). W formacjach łupkowych i pokładach węgla cel szczelinowania jest nieco inny. W obu tych skałach gaz zakumulowany został w materii organicznej, a proces jego uwalniania wiąże się ze zjawiskiem desorpcji. W związku z powyższym bardzo istotne jest utworzenie maksymalnie dużej powierzchni (matrycy spękań), na której to zjawisko może zachodzić. Powierzchnię tę stanowią ściany szczelin, dlatego im jest ich więcej, tym lepiej „desorbować się" będzie gaz uwięziony w matrycy. W związku z tym celem szczelinowania łupków i pokładów węgla jest wytworzenie w formacji złożonej sieci podsadzonych pęknięć, mikroszczelin i szczelin, na których powierzchniach gaz będzie ulegał desorpcji, a następnie przepływał nimi do odwiertu.

Pozytywne rezultaty światowych poszukiwań gazu w złożach niekonwencjonalnych oraz możliwość odkrycia znacznych akumulacji metanu w analogicznych strukturach w Polsce spowodowały spore zainteresowanie nimi w naszym kraju. W pierwszej dekadzie XXI wie$\mathrm{ku}$ rozpoczęto $\mathrm{w}$ naszym regionie prace nad udostępnianiem formacji łupkowych, które w ostatnich latach były kontynuowane. Bardzo ciekawy projekt został zrealizowany w odwiercie Stoczek-OU1K. Jest to trzeci horyzontalny otwór poszukiwawczy za gazem z łupków, wykonany przez ORLEN Upstream w 2014 roku na obszarze województwa lubelskiego. Otwór osiągnął głębokość około 2980 m TVD, udostępniając niekonwencjonalne utwory syluru. Długość horyzontalnej części otworu to około $1100 \mathrm{~m}$. Szczelinowanie hydrauliczne części horyzontalnej przeprowadzono w technologii plug and perf. W sumie w otworze wykonano 10 sekcji szczelinowania hydraulicznego. Zabiegi podzielono na dwa etapy. Pierwszy etap obejmował szczelinowanie 5 sekcji z użyciem cieczy zabiegowej na bazie polimeru, drugi został wykonany z wykorzystaniem cieczy zabiegowej typu slickwater. Koncepcję szczelinowania tego odwiertu pokazano na rysunku 4.

Rodzaj oraz całkowita ilość zatłoczonej podsadzki w każdym z etapów była taka sama, dodatki chemiczne do cieczy zabiegowej także nie ulegały zmianie. Odbiór płynu zwrotnego dla każdego z dwóch etapów przeprowadzono oddzielnie i porównano wyniki różnych technologii szczelinowania w tym samym ośrodku skalnym.

W pierwszym etapie wykonano szczelinowanie pięciu sekcji przy użyciu cieczy zabiegowej na bazie polimeru.
Etap 1: Szczelinowanie cieczą zabiegową na bazie polimeru 360,5 m

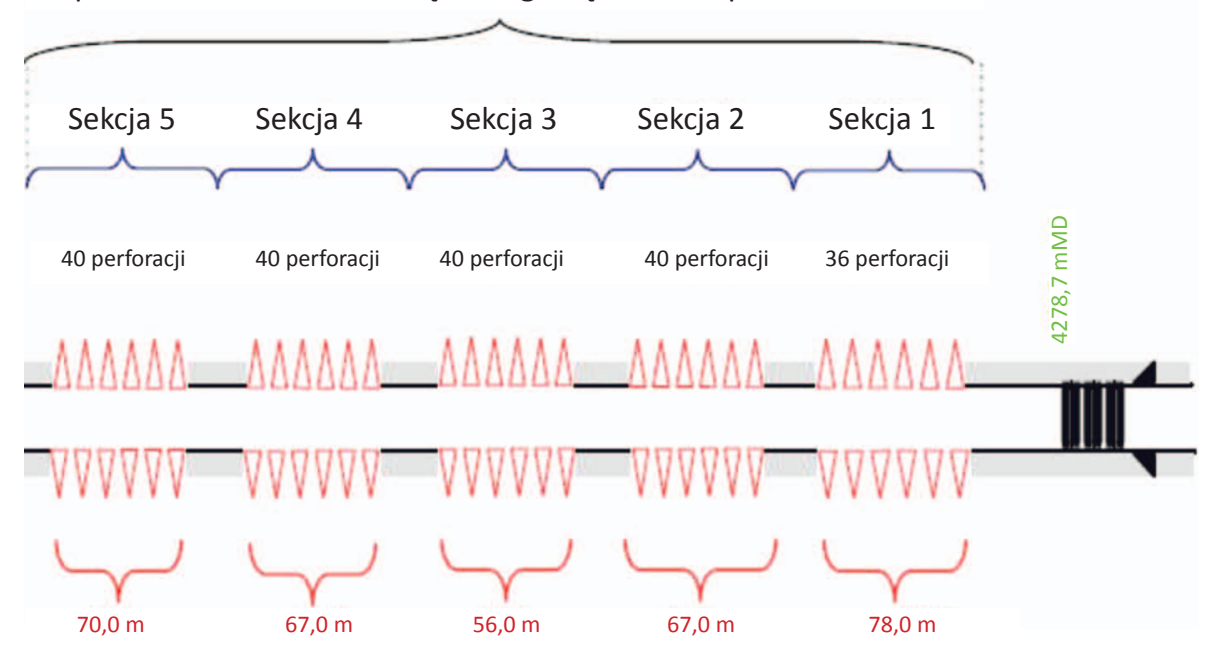

Etap 2: Szczelinowanie cieczą zabiegową typu slickwater 419,0 m

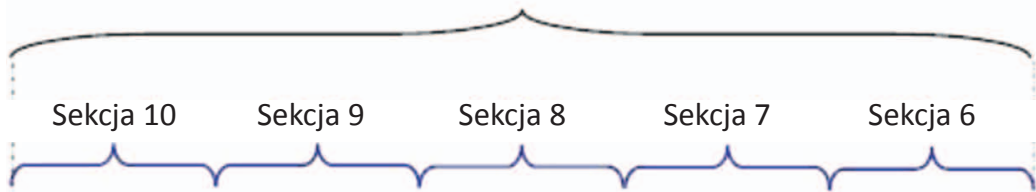

48 perforacji $\quad 48$ perforacji $\quad 50$ perforacji $\quad 48$ perforacji $\quad 48$ perforacji

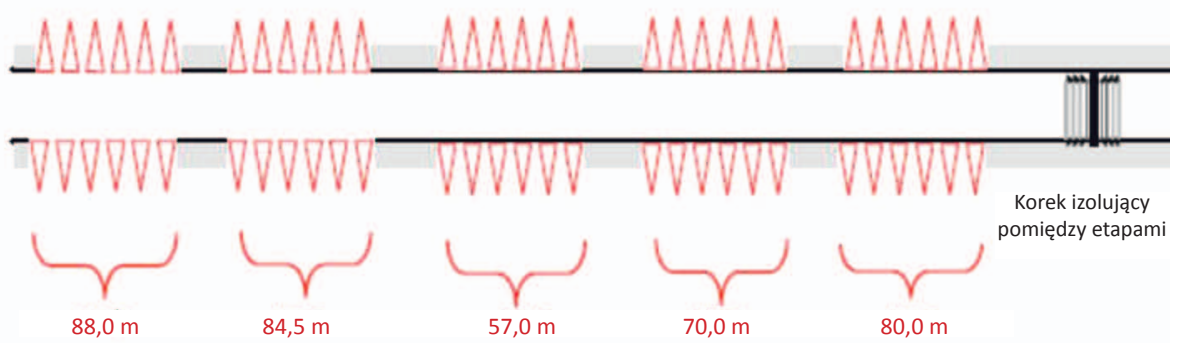

Rys. 4. Koncepcja szczelinowania odwiertu Stoczek-OU1K 
W czasie każdego z zabiegów zastosowano zarówno żel liniowy, jak i sieciowany o koncentracji polimerów około 30\# (lb/1000 gal). Całkowita ilość płynu na pięć zabiegów szczelinowania wynosiła około $5300 \mathrm{~m}^{3}$. Średni wydatek tłoczenia utrzymywano na poziomie $12,5 \mathrm{~m}^{3} / \mathrm{min}$, przy ciśnieniu zabiegowym około 720 bar. W drugim etapie wykonano szczelinowanie kolejnych pięciu sekcji z wykorzystaniem cieczy zabiegowej typu slickwater, czyli wody z dodatkiem reduktora tarcia. Całkowita ilość płynu na pięć zabiegów szczelinowania wyniosła około $14000 \mathrm{~m}^{3}$. Średni wydatek tłoczenia utrzymywano na poziomie $16 \mathrm{~m}^{3} / \mathrm{min}$, przy ciśnieniu zabiegowym około 820 bar. W każdym z dwóch etapów ilość zatłoczonej podsadzki na pięć zabiegów szczelinowania wyniosła około 600 ton. Podczas szczelinowań wtłoczono podsadzkę kwarcową 100 mesh oraz ceramiczną 40/70 mesh. Przykładowy zapis parametrów zabiegu szczelinowania z użyciem żelu liniowego i sieciowanego oraz slickwater przedstawiono na rysunkach 5 i 6 .

Zabiegi szczelinowania w każdym z etapów wykonywane były w ten sam sposób. Jak wspomniano, zasadnicza różnica pomiędzy etapami polegała na użyciu innej cieczy technologicznej. To z kolei miało znaczący wpływ na podstawowe parametry zabiegu szczelinowania. Przykładowy zapis parametrów zabiegów z poszczególnych etapów pokazano na rysunkach 5 i 6 . W pierwszym etapie, z zastosowaniem żelu, zabieg wykonano przy wydajności tłoczenia około $13 \mathrm{~m}^{3} / \mathrm{min}$ (80 bpm). Przy tej wydajności średnie ciśnienie tłoczenia było równe około 655 bar (9500 psi). Maksymalna koncentracja podsadzki w płynie szczelinującym na bazie żelu wynosiła około $476 \mathrm{~kg} / \mathrm{m}^{3}$ (4 lb/gal). Zabiegi w drugim etapie wykonane zostały w technologii slickwater. W tym przypadku wydajność tłoczenia wynosiła około $16 \mathrm{~m}^{3} / \mathrm{min}$ (100 bpm). Przy takim reżimie prowadzenia zabiegów średnie ciśnienie tłoczenia wynosiło około 758 bar (11 000 psi), natomiast maksymalna uzyskana koncentracja podsadzki w płynie szczelinującym to około $119 \mathrm{~kg} / \mathrm{m}^{3}$ (1 lb/gal).

Odbiór płynu zwrotnego prowadzono w każdym z dwóch etapów. W obu przypadkach trwał on 7 dni. Bezpośrednio po uruchomieniu otworu odbierano płyn zwrotny, dławiąc przepływ, potem następował przepływ niedławiony, a w ostatniej fazie zastosowano gazodźwig, wspomagając azotem wydobycie płynu pozabiegowego. Podczas odbioru cieczy pozabiegowej po pierwszym etapie szczelinowania hydraulicznego odebrano jej około $1640 \mathrm{~m}^{3}$ (28\% ilości zatłoczonej cieczy). Ilość odebranego gazu ziemnego wyniosła około $7600 \mathrm{Nm}^{3}$. Podczas odbioru cieczy pozabiegowej po drugim etapie szczelinowania hydraulicznego odebrano jej około $2793 \mathrm{~m}^{3}$ (18\% ilości zatłoczonej cieczy). Ilość odebranego gazu ziemnego wyniosła około $17000 \mathrm{Nm}^{3}$. Dla potrzeb gazodźwigu zużyto ponad 100 ton azotu na każdym z etapów.

Innowacyjne na skalę europejską zastosowanie dwóch metod szczelinowania w jednym otworze horyzontalnym i selektywny odbiór płynu zwrotnego dały możliwość porównania dwóch różnych technologii szczelinowania tych samych utworów syluru. Porównanie dotyczyło zarówno zachowania skały zbiornikowej, jej podatności na szczelinowanie, w przypadku zastosowania dwóch różnych technologii stymulacji, jak i uzyskanych efektów.

\subsection{Attachments}

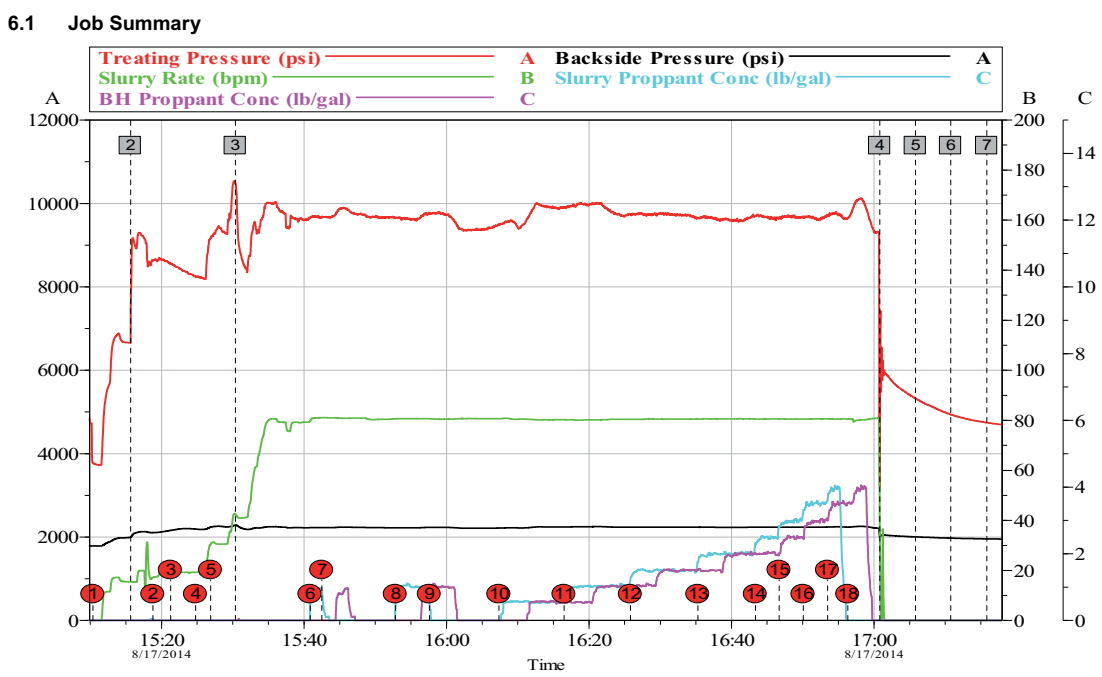

Rys. 5. Szczelinowanie żelami

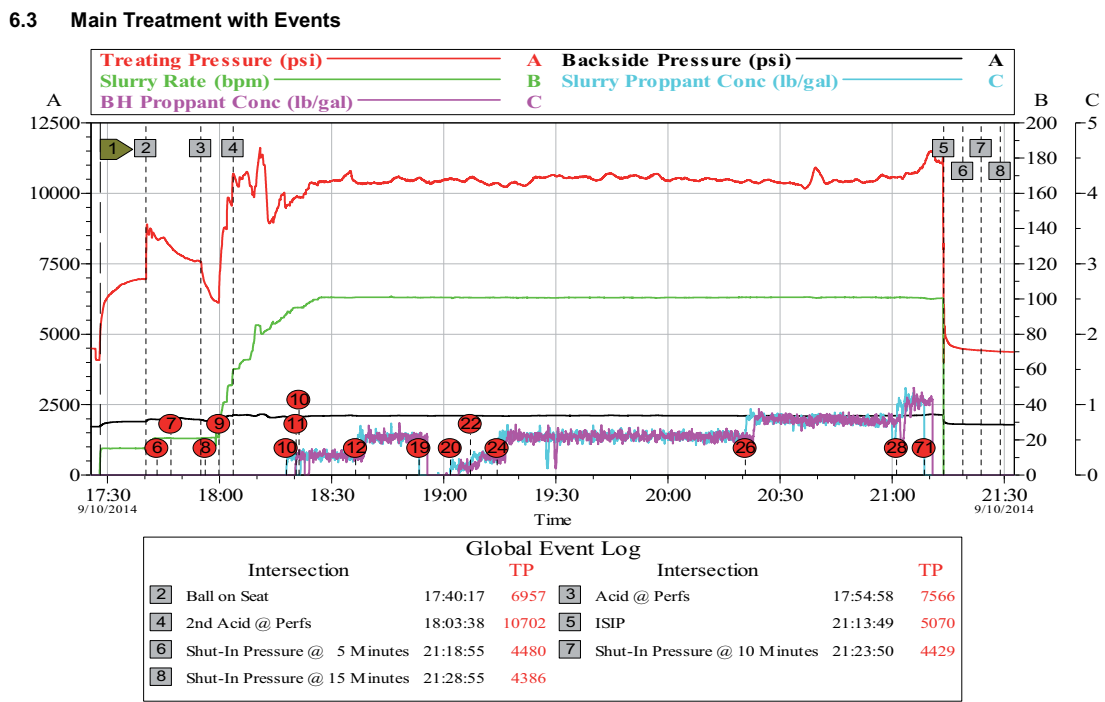

Rys. 6. Szczelinowanie slickwater 
Pierwsze kroki w udostępnianiu złóż niekonwencjonalnych w Polsce zostały już poczynione. Koncentrowały się one do tej pory na łupkach gazonośnych, przy których udostępnianiu pracowało wiele firm krajowych i zagranicznych. Po kilku latach sporej aktywności w tym obszarze nie udało się uzyskać w pełni zadowalających wyników. Wśród możliwych i bardzo prawdopodobnych przyczyn są: własności skały mułowcowo-ilastej, brak odpowiedniej technologii udostępniania, a także niewystarczająca liczba zrealizowanych na terenie naszego kraju szczelinowań. W świetle badań wykonanych w INiG - PIB jednym z kluczowych czynników obniżających efektywność zabiegów szczelinowania polskich łupków jest zjawisko embedmentu. Polega ono na wciskaniu podsadzki w ściany szczeliny. W pewnych warunkach może ono być tak intensywne, że mimo podsadzenia szczeliny ulega ona całkowitemu zaciśnięciu.

Obecnie trwają prace nad rozpoznaniem i udostępnieniem innych typów złóż niekonwencjonalnych. Konieczne będzie opracowanie w najbliższym czasie skutecznej techniki i technologii udostępniania formacji tight, w których potwierdzono znaczne akumulacje metanu.

W przypadku szczelinowania hydraulicznego w słabo przepuszczalnych piaskowcach o stosunkowo dużej miąższości, bez ryzyka występowania wody podścielającej oraz z ewentualną obecnością naturalnych szczelin, autorzy artykułu proponują wykorzystanie technologii znanej ze szczelinowania otworów poszukiwawczych gazu z łupków w Polsce. Technologia ta dzięki zastosowaniu dużych objętości mało lepkiej cieczy zabiegowej wspiera kompleksowość szczelin, a co za tym idzie - pozwala udostępnić dużą objętość skały złożowej. Proppant o małej granulacji oraz duże wydatki tłoczenia poprawiają podsadzanie szczelin w znacznej odległości od otworu. Dodatkowo duże wydatki tłoczenia przeciwdziałają ucieczce cieczy zabiegowej w ewentualnie występujące naturalne szczeliny. Dodatkowo zastosowanie cieczy zabiegowej typu slickwater nie powoduje znacznego uszkodzenia powierzchni kontaktu szczelin z matrycą skalną ze względu na znikomą ilość dodawanego polimeru.

Inną technikę szczelinowania można zastosować w słabo przepuszczalnych piaskowcach o małej miąższości, gdy występują problemy z aktywną wodą podścielającą. W tych przypadkach autorzy proponują wykorzystanie technologii selektywnej dystrybucji podsadzki wzdłuż interwału nasyconego węglowodorami. Znana jest ona w literaturze pod pojęciem pipelining i znalazła szerokie zastosowanie w piaskowcowych złożach węglowodorów w regionie basenu permskiego Delaware w USA, gdzie problem występowania wody podścielającej ma istotne znaczenie. Jednym z głównych kryteriów pozwalających wykonać zabieg z sukcesem jest perforacja dokładnie w warstwie, gdzie występuje nasycenie węglowo- dorami. Technologia polega na zatłaczaniu w pierwszej kolejności sieciowanego żelu o dużej lepkości (PAD). Powoduje to powstanie szczelin o znacznych rozmiarach (większych niż miąższość formacji złożowej). W kolejnym etapie wtłaczany jest proppant $\mathrm{z}$ płynem o lepkości nawet do pięćdziesięciu razy mniejszej niż płyn PAD. Obecność bardzo lepkiego płynu w szczelinie powoduje, że wpływający płyn o małej lepkości penetruje przede wszystkim sperforowaną serię złożową (zjawisko viscous fingering), która zostaje wypełniona znaczną ilością wtłoczonego proppantu. Dodatkowo zastosowanie techniki natychmiastowego odbioru płynu pozabiegowego ze szczeliny powoduje wymuszone i szybkie jej zamknięcie. Sprawia to, że podsadzka nie ma możliwości grawitacyjnego opadania w dół szczeliny, poniżej perforacji.

Kolejne poważne wyzwanie stanowi uzyskanie komercyjnej produkcji metanu zakumulowanego w pokładach węgla. Jeżeli pozyskiwanie metanu prowadzone jest otworami wiertniczymi z powierzchni poza obszarami objętymi klasyczną działalnością górniczą mówimy o tzw. CBM (coal bed methane). Prowadząc z kolei działalność górniczą w kopalniach węgla kamiennego, w obszarach dużej metanowości, wykonuje się prace w celu odmetanowania kopalń. Dodatkowo możliwe jest odzyskanie metanu z powietrza wentylacyjnego. Tak uzyskany metan określany jest mianem CMM (coal mine methane). Po zakończeniu eksploatacji górniczej pozostawiony węgiel nadal może desorbować uwięziony metan. Ujmowanie metanu z wyeksploatowanych kopalń nosi nazwę AMM (abandoned mine methane). Zagospodarowanie metanu CMM jest realizowane już od wielu lat. Pierwsze projekty pozyskania metanu z węgla działały w Polsce już w latach dziewięćdziesiątych ubiegłego stulecia. W tym czasie poszukiwania prowadziło kilka firm, które nie uzyskały jednak zadowalających wyników i zrezygnowały z dalszych prac. Prawdopodobną przyczyną był brak odpowiedniej technologii szczelinowania węgla. Obecnie inicjowane są kolejne projekty mające na celu uruchomienie wydobycia metanu z pokładów węgla metodą CBM. Szanse na powodzenie realizowanych prac są teraz znacznie większe. Związane jest to przede wszystkim z ogromnym postępem technologicznym, jaki dokonał się przez ostatnie lata. Opracowanie i doskonalenie technologii szczelinowania formacji łupkowych może być wykorzystane w przypadku szczelinowania węgla.

Przedstawione powyżej kierunki stanowią najbliższą perspektywę prac nad odkrywaniem nowych złóż i pozyskiwaniem metanu z formacji niekonwencjonalnych. Motywacja do uzyskania pozytywnych wyników tej działalności związana jest przede wszystkim z potwierdzonymi akumulacjami gazu w tych skałach. Zastosowanie skutecznych technik i technologii ich udostępniania z pewnością przybliży firmy do sukcesu komercyjnego tych przedsięwzięć. 
Prosimy cytować jako: Nafta-Gaz 2016, nr 10, s. 779-804, DOI: 10.18668/NG.2016.10.04

Artykuł nadesłano do Redakcji 3.09.2016 r. Zatwierdzono do druku 26.10.2016 r.

Artykuł powstał na podstawie umowy ramowej pomiędzy ORLEN Upstream a Instytutem Nafty i Gazu - Państwowym Instytutem Badawczym nr OU/184/2014 z dnia 2.06.2014 r.

\section{Literatura}

[1] Czupski M., Kasza P., Wilk K.: Płyny do szczelinowania złóż niekonwencjonalnych. Nafta-Gaz 2013, nr 1, s. 42-50.

[2] Ely J. W., Hargrove J. S., Wolters B. C., Kromer J. C.: ,,Pipelining”. Viscous Fingering Prop Fracture Technique Finds Wide Success in Permian and Delaware Basins, SPE 26528, SPE ATCE, Houston 1993.

[3] Gidley J. L., Holditch S. A., Nierode D. E., Veatch Jr. R. W.: Recent Advances in Hydraulic Fracturing. SPE Monograph Series, vol. 12. Society of Petroleum Engineers, 1990.

[4] Kasza P.: Zabiegi stymulacji wydobycia w niekonwencjonalnych złożach węglowodorów. Nafta-Gaz 2011, nr 10, s. 697-701.

[5] King G. E.: Thirty Years of Gas Shale Fracturing: What Have We Learned. SPE 133456, SPE ATCE, Florence 2010

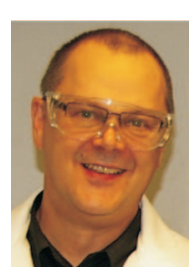

Dr inż. Piotr KASZA

Adiunkt; kierownik Zakładu Stymulacji Wydobycia Węglowodorów.

Instytut Nafty i Gazu - Państwowy Instytut Badawczy ul. Lubicz 25 A

31-503 Kraków

E-mail:piotr.kasza@inig.pl

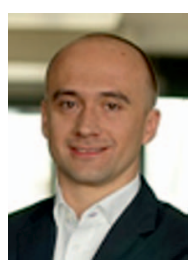

Piotr KENAR

Dyrektor Pionu Wydobycia

ORLEN Upstream

ul. Prosta 70

00-838 Warszawa

E-mail: Piotr.Kenar@orlen.pl

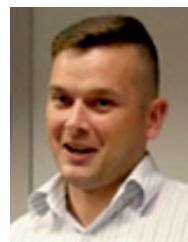

Wojciech PIĘTKA

Specjalista ds. intensyfikacji przepływu

ORLEN Upstream

ul. Prosta 70

00-838 Warszawa

E-mail: Wojciech.Pietka@orlen.pl

\section{OFERTA}

\section{ZAKŁAD STYMULACJI WYDOBYCIA WĘGLOWODORÓW}

Zakres działania:

- $\quad$ przygotowywanie receptur i badania płynów zabiegowych do stymulacji wydobycia ropy i gazu;

- $\quad$ symulacje przepływów i badania reologiczne w skali półtechnicznej;

- badania materiałów podsadzkowych:

- badania przewodności szczeliny w zależności od użytego materiału podsadzkowego i płynu zabiegowego;

- $\quad$ symulacje usuwania uszkodzenia strefy przyodwiertowej;

- oznaczanie współczynnika przepuszczalności i porowatości skał, kamienia cementowego, betonu itp.;

- dobór środków regulujących właściwości reologiczne płynów (SPCz, polimery itp.);

- badania szybkości reakcji skał złożowych z cieczami kwasującymi;

- laboratoryjne symulacje zabiegów kwasowania w warunkach złożowych;

- $\quad$ wykonywanie projektów technologicznych zabiegów stymulacji;

- $\quad$ analiza testów miniszczelinowania i analiza pozabiegowa;

- laboratoryjne symulacje metod wspomagających wydobycie węglowodorów;

- badania zjawisk korozyjnych występujących w górnictwie naftowym;

- dobór ochrony inhibitorowej zapobiegającej zjawiskom korozyjnym.

Kierownik: dr inż. Piotr Kasza

Adres: ul. Armii Krajowej 3, 38-400 Krosno

Telefon: 134368941 w. 5229

Faks: 134367971

E-mail: piotr.kasza@inig.pl

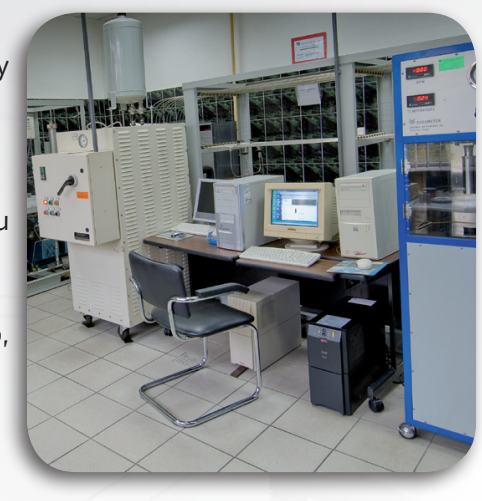

